\title{
Predictive mapping of floristic site conditions across mire habitats: Evaluating data requirements
}

\author{
K. Ecker ${ }^{1}$, M. Küchler ${ }^{2}$, E. Feldmeyer-Christe ${ }^{3}$, U. Graf $^{3}$ and L. T. Waser ${ }^{4}$ \\ ${ }^{1}$ Corresponding author. Biodiversity and Conservation Biology Research unit, Swiss Federal Research Institute \\ WSL, Zürcherstrasse 111,8903 Birmensdorf,Switzerland.E-mail: klaus.ecker@wsl.ch \\ ${ }^{2}$ Community Ecology Research unit, Swiss Federal Research Institute WSL, Zürcherstrasse 111, 8903 Birmensdorf, \\ Switzerland.E-mail:meinrad.kuechler@wsl.ch \\ ${ }^{3}$ Community Ecology Research unit, Swiss Federal Research Institute WSL, Zürcherstrasse 111, 8903 Birmensdorf, \\ Switzerland.E-mail: elizabeth.feldmeyer@wsl.ch,ulrich.graf@wsl.ch \\ ${ }^{4}$ Land-Resource Assessment Research unit, Swiss Federal Research Institute WSL, Zürcherstrasse 111, \\ 8903 Birmensdorf, Switzerland.E-mail: lars.waser@wsl.ch
}

Keywords: Aerial photography, Bog, Ellenberg indicator values, Linear regression, Nature conservation, Remote sensing, Sampling design, Switzerland, Vegetation, Wetland.

\begin{abstract}
As conservation of sensitive habitats is a high priority issue in European environmental policy, there is considerable interest in mapping and monitoring specific habitats of high conservation value. In this study, we discuss the potential of the Swiss mire monitoring program to monitor small area habitats in sufficient detail. The monitoring scheme combines nationwide probability sampling and predictive habitat mapping based on a field data sample. Thus, it is designed to identify spatiotemporal changes at the stand level and to derive hard statistics for the sub-national level. For feasibility reasons, the thematic focus is on semi-quantitative mean indicator values derived from vegetation records. These measures provide robust estimates of essential floristic site conditions. Regression models based on CIR aerial photographs are applied to continuously map respective measures across the sample mires. The present study explores the required investment of data for model-based mapping. Exemplary mapping results are presented and validated within a reference mire. Repeated tests show that about one hundred field records are needed to guarantee optimal prediction accuracy and reliable error estimates for all target variables. The corresponding $95 \%$ error quantiles in a test data set are below 0.7 . To evaluate the benefit of high resolution orthophotos ( $30 \mathrm{~cm}$ resolution), the model prediction is compared with results obtained from coarsened images. Although the original CIR images produce the best model performance, the models based on resolutions comparable to modern satellite images still show considerable potential to assess larger areas where the use of digital aerial photographs is limited. The resulting spatially-explicit in-depth information can resolve the common thematic limitations of stand-alone remote sensing applications in conservation monitoring. As the method is applicable consistently across a range of habitat types, we argue that it has the potential to become a standard method for operational monitoring of priority habitats in European nature conservation.
\end{abstract}

Abbreviations: ASTER - Advanced Spaceborne Thermal Emission and Reflection Radiometer, CIR - Colour infrared, DSM - digital surface model, DTM - digital terrain model, NIR - Near infrared, VHSR - Very high spatial resolution, VHR - Very high resolution.

\section{Introduction}

Intensification in agriculture, tourism, fragmentation and periodic water shortages are among the main threats to temperate zone wetlands today. Hence, conservation of such natural and semi-natural habitats is a high priority issue in European environmental policy. The most wide-ranging legislations are the recent European Union Habitats Directive (92/43/EEC) and Water Framework Directive (WFD; 2000160/EC) which include provisions for enhancing ecosystem health and prevention of further deterioration of aquatic ecosystems, including wetlands (Large et al. 2007). At the national level, Switzerland has adopted an even more rigorous initiative for enhanced site protection and/or restoration of mire ecosystems. According to a federal decree from 1987, Swiss mires of national importance, as defined in national inventories, have to be maintained in their present size and quality. The definition comprises all wetlands with the exception of floodplains and fen woodland. It is the duty of the cantons to implement compulsory mire conservation programs including appropriate agricultural practices in semi-natural wetlands.

The question arises whether the induced management activities actually meet the objectives of conservation legislation and justify the high level of public and private expenditure involved. In Europe and North America, large agri-environment schemes spend billions of dollars, but recent efforts to document their effectiveness have been patchy or have produced mixed results (Bunce et al. 2008). Hence, 
there is an ongoing debate on the ecological benefits of such programs (Kleijn et al. 2006, Field et al. 2007) .

Therefore, monitoring the efficacy of management activities is strongly recommended to be an integral component of the design and implementation of any nature conservation program (Christensen et al. 1996, Woodward et al. 1999, Vos et al. 2000, Nichols and Williams 2006, Pereira and Cooper 2006). Monitoring is defined as 'intermittent recording of the condition of a feature of interest to detect or measure compliance with a predetermined standard' (Hellawell 1991). According to Legg and Nagy (2006), the main tasks of monitoring nature conservation are: to inform the conservationist when the system is departing from the desired state, to measure the success of management actions, and to detect the effects of perturbations and disturbances. When the objectives of the study are well defined, conservation monitoring becomes an essential tool for identifying changes in ecosystems with implications for applied research and management (Yoccoz et al. 2001). As the Swiss mire monitoring program is designed as a screening and verification procedure, its character is operational rather than investigative (Ferreira et al. 2007).

At the level of the European Union Habitats Directive (92/43/EEC), reporting is still based on individual national programs without standardised protocols. As a result, there are no consistent figures on habitat loss and the state of the habitats for European priority habitats. Most of the available maps are derived from satellite imagery and are not sufficiently detailed for strategic policy making (Bunce et al. 2008). Thus, operational monitoring of European priority habitats addressing habitat extent as well as conservation state is urgently needed.

However, reduced financial resources and the inevitable trade-off between biological details and data availability readily provokes the use of direct or indirect attributes derived from remotely sensed data. In fact, recent advances in earth observation techniques have reduced the perceived mismatch between information obtained from stand-alone remote sensing systems and in-depth information of traditional field work. Nevertheless, satellite imagery still has to be supported by field measurements to provide meaningful ecological information (Kerr and Ostrovsky 2003, Turner et al. 2003, Kerr and Deguise 2004, Fassnacht et al. 2006). Recent case studies on small area monitoring of spatially heterogeneous wetland habitats corroborate its ongoing dependence on ancillary field observations (Weiers et al. 2004, Bock et al. 2005, Belluco et al. 2006, Langanke et al. 2007).

The study presented here outlines the potential of the Swiss mire monitoring program to solve the stated survey problem of remote sensing data in operational conservation monitoring. The monitoring design combines nation-wide probability sampling and predictive habitat mapping based on a field data sample to identify subtle spatio-temporal changes at the stand level and to derive hard statistics for the sub-national level. The latter is especially needed for the development of strategic conservation policies.
To capture essential attributes of the state of a mire ecosystem the primary monitoring focus is on floristic conditions at the stand level. These are specified by quasi-metric mean indicator values derived from vegetation records collected in the field (Ellenberg 1974, Landolt 1977, Ellenberg et al. 1992). As floristic habitat gradients of interest are continuous in nature, these measures are more likely to capture subtle shifts within heterogeneous semi-natural ecosystems than simplified vegetation classes or habitat types. Ellenberg indicator values have been used to analyse e.g., nationalscale vegetation change across Britain (Smart et al. 2003), air pollution effects on Swedish boreal forests (Grandin 2004), soil eutrophication and acidification in German forest ecosystems (Seidling 2005), environmental changes in wetland sites with a view to their management (Large et al. 2007) or bog slide (Feldmeyer-Christe and Küchler 2002).

To provide estimates over the whole area of observation, regression models based on CIR aerial photographs are employed for continuous mapping of respective floristic gradients within all sample mires. Such empirical models are an important tool for relating field-measured biophysical variables to remote sensing data (Pietroniro and Leconte 2005, Fassnacht et al. 2006). Recent studies have used such models to map forest attributes over large areas (Cohen et al. 2003, McRoberts 2006) or to estimate hydrological state parameters within wetlands (Pietroniro and Leconte 2005). Few authors have used variables derived from species composition to continuously map floristic conditions across complex stands (Küchler et al. 2004, Schmidtlein 2005, Schmidtlein et al. 2007). One article presents how to use respective model estimates for spatio-temporal change detection (Küchler et al. 2007).

As budgets are tight in most conservation monitoring studies, survey efficiency is crucial especially for obtaining costly ground truth and VHSR remotely sensed data. In this paper, we test the sample size needs for predictive mapping of mean indicator values with pre-defined minimum accuracy. To assess the minimum spatial resolution of remotely sensed data that still allows for the presented stand level mapping, CIR orthophotos $(30 \mathrm{~cm}$ resolution) are compared to simulated satellite images in terms of predictive power in regression models. For that we use coarsened CIR imagery with ground resolutions of $5 \mathrm{~m}$ and $15 \mathrm{~m}$.

\section{Material and methods}

\section{National sampling design}

The nation-wide monitoring project was established in 1996 to reveal as early as possible any discrepancies between conservation goals and real developments. It has to be a practical instrument to provide the people in charge with scientific results in order to assess and readapt, if necessary, their earlier policies. Considering the spatial heterogeneity and small size of most of the Swiss mire remnants monitoring has to focus on the stand level. To provide valid data for the whole country, a stratified random sample was drawn from 


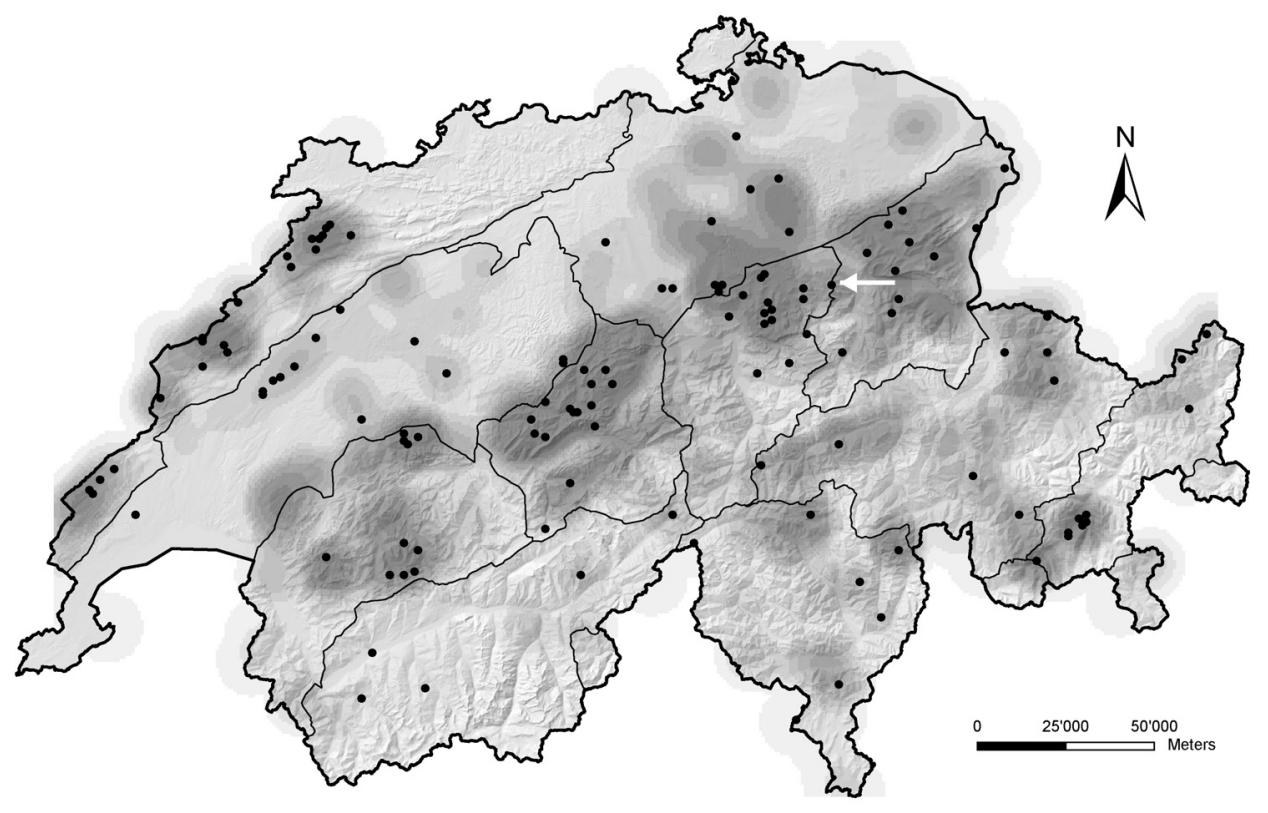

Figure 1. Distribution of bogs and fens of national importance in Switzerland. The densities of occurrence are indicated by the darkness of the grey colours. 124 black dots mark the monitoring objects selected by a stratified random sampling procedure. The additional Case Study Area of Gross Moos in the Canton of Glarus is indicated by an arrow.

the entire variety of managed and unmanaged mire ecosystems listed in the federal mire inventories (Grünig et al. 1986, Broggi 1990). The sampling takes into account the geographic region, the altitudinal belt, the type (bog or fen) and the size of each mire. The resulting selection comprises 103 mire sites and 21 partial replacement objects for the second survey update (Fig. 1) whereas 18 additional mires serve as reference. The reference sites are investigated in more detail to assess the causes of possible changes.

\section{Study area}

The mire site chosen for exemplary model demonstration in this study is one of the reference objects. "Gross Moos" is located in Schwändital on the northern slope of the Swiss Alps at an altitude of about $1250 \mathrm{~m}$ (Fig. 1). It is a percolated sloping bog of about 16 ha. Heavy degradation resulted from draining ditches and grazing. Since the mire became protected, great efforts have been made to restore the site. Cattle were gradually kept away from the site and a big ditch in the centre was filled up with sawdust to raise the ground water level.

\section{Field survey based on local sampling}

Data collection consists of image segmentation and field sampling.

Image segmentation is realized by visual photographic interpretation of overlapping pairs of analogue CIR aerial photos with a scale of 1:5000 under a stereoscope. Vegetation patches which meet specific criteria of homogeneity in terms of colour, texture and structure, are delineated.
Field survey is restricted to a limited number of the homogeneous vegetation patches, selected by local stratified random sampling (Fig. 2). To update sample representativeness, sampling within the mire object is repeated at each survey by partial replacement. Field work consists of taking a full record of vascular plants and bryophytes. The vegetation relevés include abundance data for vascular plants and mosses and cover estimations for trees, Sphagnum species in total, bare peat and open water. For predicting indicator values, we use basic presence/absence data as these measures show the best model results. Within the reference mire "Gross Moos", the entire area under observation was recorded in 1996 for in-depth monitoring of given restoration activities. Additionally, a sample of 283 records was drawn in 2001 .

Monitoring status quo. Between 1996 and 2007, 32,000 vegetation relevés were taken in the course of the Swiss mire monitoring program. The time span between surveys is five years. The second survey started in 2003 and will end in 2008. Then spatio-temporal changes in Swiss mire habitats will be investigated.

\section{Continuous mapping of floristic conditions at the stand level}

Target variables. Our study focuses on the spatio-temporal variation of mean indicator values derived from presence/absence vegetation data recorded in the field. Indicator values characterise the realized optima (Hutchinson 1957) of organisms along multiple environmental gradients in their natural surrounding. As these indicator values take into account physiological limitations and competition of other organ- 


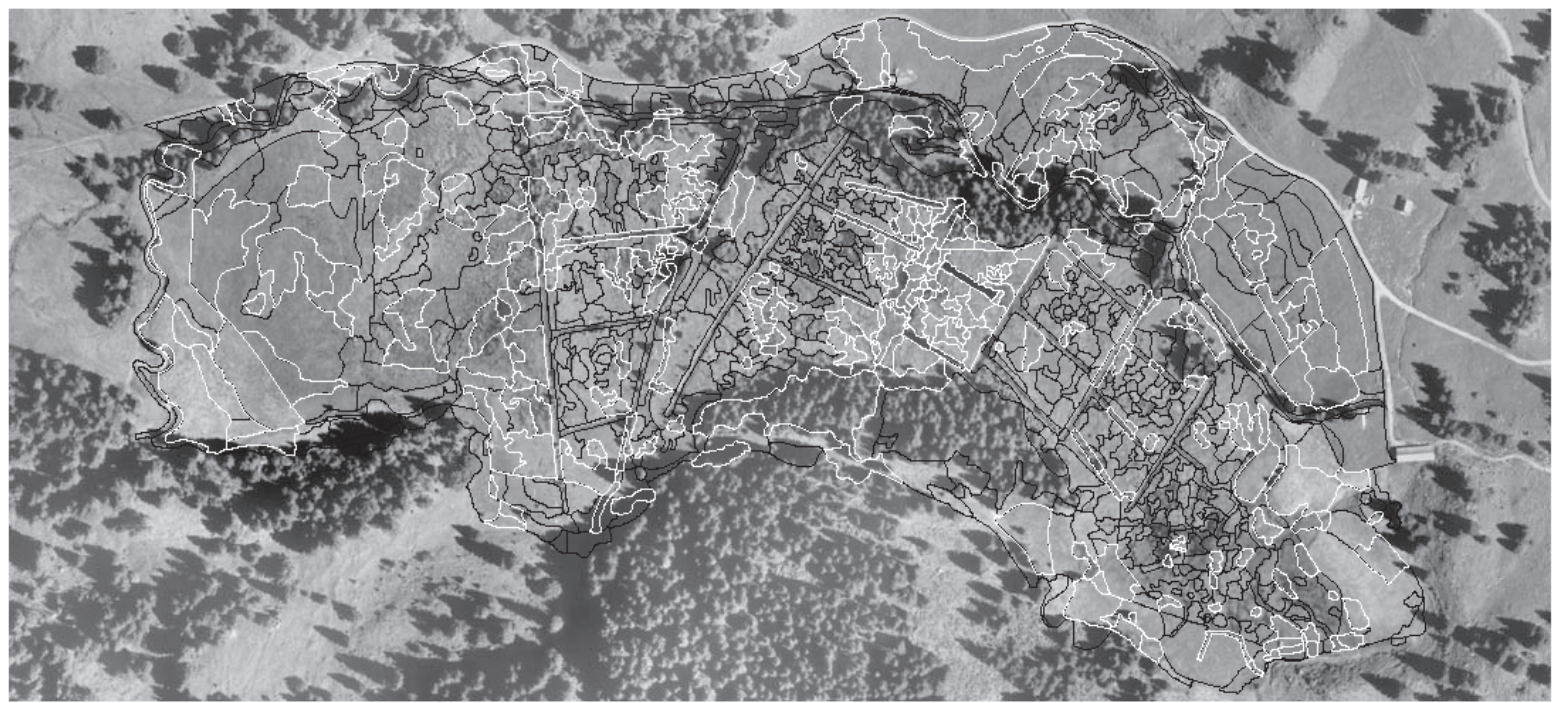

Figure 2. Monochrome CIR orthoimage of the reference mire Gross Moos in 2001, superimposed with an a priori delineation of 1036 floristic groupings, resulting from visual photo interpretation. The 283 plots selected for field work are outlined in white.

isms, they can be considered plant functional response. Their definition along an ordinal scale is mainly based on field experience. The indicator values assigned to vascular plants by Ellenberg for Central Europe (Ellenberg 1974, Ellenberg et al. 1992) and adopted by Landolt for Switzerland (Landolt 1977) are most common. Landolt indicator values are defined for light, continentality, temperature, moisture, soil reaction, nitrogen, salt tolerance, humosity and dispersity.

When geo-chemical and geo-physical measurements of environmental variables are not available, the system of indicator values is considered to be a practicable way to indirectly quantify stand level conditions by averaging the indicator values of all species within a surface. Such mean indicator values describe the realized niche of a species assemblage. Communities generally integrate the individual overlapping resource requirements and ecological tolerances that emerge from competitive processes as well as historical and other stochastic effects. Consequently, the optimum in the multidimensional ecological space is more uniform for communities than for their species (Zimmermann and Kienast 1999). Therefore, using the overall balance of species increases the chance to derive accurate mean indicator values for the underlying site factors (Bunce et al. 2008).

In this study, the calculation of the mean indicator values is carried out by the $10 \%$ trimmed mean. Instead of using original Landolt values directly, we adapt these for Swiss mire ecosystems. The habitat-specific re-calibration is accomplished by the means of weighted averaging of 10.000 vegetation records from the monitoring program. The new values are refined and scaled continuously from 0 to 6 . Thus, we do not solve the problem of non-equidistance measures, but it was demonstrated that such re-recalibration based on empiric data enhances the accuracy of derived predictive maps within Swiss mire ecosystems (Feldmeyer-Christe et al. 2007).

Empirical modelling. We use linear regression models based on remotely sensed data for predicting continuous mean indicator values within the whole mire area. The modelling chosen for this study relies on ordinary least squares regression and is calibrated by mean indicator values derived from the field samples.

To provide sensitive predictor variables for reliable modelling, we derive various attributes from VHR remotely sensed data. Table 1 lists the corresponding processing algorithms, the estimates calculated to retrieve the information at the polygon level and their ecological relevance. Spectral and textural characteristics are extracted from CIR orthoimages of $30 \mathrm{~cm}$ ground resolution to capture vegetation composition at a fine scale. High resolution surface models with a grid spacing of $50 \mathrm{~cm}$, generated by automated image matching, and broad-scale terrain models of $25 \mathrm{~m}$ ground resolution are used to reflect vegetation structure and vegetation response to topographical gradients (Moore et al. 1991, Dirnböck et al. 2002). The up-scaling of the fine-grained remotely sensed information to the spatial modelling units - the patches - is carried out by calculating summary statistics such as relative proportions, arithmetic mean, median and variance values for each polygon. Thus, we generate spectral, spectral-textural, topographical and topographical-textural variables, resulting in about 130 variables describing each polygon.

In order to satisfy linearity conditions, the following types of predictor variables are transformed: variances are replaced by their square root before entering the model, proportions are transformed by computing the arc sine of the square root (Zar 1986, Schlittgen 2000). 
Table 1. Spectral and topographical variables used for predicting a-priori delineated polygons. Upscaling of the fine-coarse remotely sensed data to the spatial modelling units - the patches - is realized by calculating summary statistics: proportion, arithmetic mean, median and variance values for the polygon. In the table, the variables are arranged in thematically coherent sections. The lines group the variables derived from a specific thematic product (column 1). The other columns give the processing algorithm (2), the primary data source (3), the number (4) and kind (5) of variables calculated for information upscaling and their environmental relevance (6).

\begin{tabular}{|c|c|c|c|c|c|}
\hline Thematic product & Processing algorithm & $\begin{array}{l}\text { Data } \\
\text { source }\end{array}$ & $\mathrm{Nr}$ & $\begin{array}{l}\text { Measures } \\
\text { calculated for } \\
\text { upscaling }\end{array}$ & Environmental relevance \\
\hline \multicolumn{6}{|l|}{ Spectral variables } \\
\hline $\begin{array}{l}\text { Colour bands (3layers) } \\
\text { near infrared ( } 750-1000 \mathrm{~nm}) \\
\text { visible red }(600-700 \mathrm{~nm}) \\
\text { visible green }(500-600 \mathrm{~nm})\end{array}$ & Raw data & $\begin{array}{l}\mathrm{CIR} \\
\text { image }\end{array}$ & 9 & $\begin{array}{l}\text { Mean, median } \\
\text { and variance of } \\
\text { each CIR colour } \\
\text { band }\end{array}$ & $\begin{array}{l}\text { Spectral reflectance, absorption and } \\
\text { transmission of the vegetation cover }\end{array}$ \\
\hline $\begin{array}{l}\text { Colour bands (3layers) } \\
\text { near infrared }(750-1000 \mathrm{~nm}) \\
\text { visible red }(600-700 \mathrm{~nm}) \\
\text { visible green }(500-600 \mathrm{~nm})\end{array}$ & Raw data & $\begin{array}{l}\mathrm{CIR} \\
\text { image }\end{array}$ & 6 & $\begin{array}{l}\text { Ratio of each } \\
\text { colour band } \\
\text { mean (and } \\
\text { median) to the } \\
\text { sum of all band } \\
\text { values. }\end{array}$ & $\begin{array}{l}\text { Calibrated spectral reflectance, } \\
\text { absorption and transmission of the } \\
\text { vegetation cover to standardize } \\
\text { photographic effects. }\end{array}$ \\
\hline $\begin{array}{l}\text { Normalized Difference } \\
\text { Vegetation Index (NDVI) }\end{array}$ & $(\mathrm{NIR}-\mathrm{red}) /(\mathrm{NIR}+\mathrm{red})$ & $\begin{array}{l}\mathrm{CIR} \\
\text { image }\end{array}$ & 3 & $\begin{array}{l}\text { Mean, median } \\
\text { and variance }\end{array}$ & $\begin{array}{l}\text { LAl, chlorophyll content, above- } \\
\text { ground phytomass, net primary } \\
\text { production }\end{array}$ \\
\hline $\begin{array}{l}\text { Enhanced Vegetation Index } \\
\text { (EVI) }\end{array}$ & $\begin{array}{l}2.5^{*}(\mathrm{NIR}-\mathrm{red}) /\left(\mathrm{NIR}+\mathrm{red}+5^{*} \mathrm{red}+\right. \\
\left.7.5^{*} \text { green }+1\right)\end{array}$ & $\begin{array}{l}\text { CIR } \\
\text { image }\end{array}$ & 3 & $\begin{array}{l}\text { Mean, median } \\
\text { and variance }\end{array}$ & $\begin{array}{l}\text { Modification of the NDVI including } \\
\text { an atmospheric correction factor }\end{array}$ \\
\hline $\begin{array}{l}\text { Modified Soil Adjusted } \\
\text { Vegetation Index (MSAVI2) }\end{array}$ & $\begin{array}{l}0.5^{*}\left(2^{*}(\mathrm{NIR}+1)-\left(2^{*} \mathrm{~N} / \mathrm{R}+1\right)^{\wedge} 2-8^{*}(\mathrm{NIR}\right. \\
\left.-\mathrm{red})^{\wedge} 0.5\right)\end{array}$ & $\begin{array}{l}\text { CIR } \\
\text { image }\end{array}$ & 3 & $\begin{array}{l}\text { Mean, median } \\
\text { and variance }\end{array}$ & Simple transformation of the NDVI \\
\hline \multicolumn{6}{|l|}{ Spectral-textural variables } \\
\hline $\begin{array}{l}24 \text { colour classes ( } 24 \\
\text { layers) }\end{array}$ & ISODATA image classification & $\begin{array}{l}\mathrm{CIR} \\
\text { image }\end{array}$ & 24 & $\begin{array}{l}\text { Relative } \\
\text { proportion of } \\
\text { each colour class }\end{array}$ & $\begin{array}{l}\text { Spatial distribution of spectrally } \\
\text { similar vegetation units }\end{array}$ \\
\hline $\begin{array}{l}\text { Colour class agglomeration } \\
\text { (24 layers) }\end{array}$ & $\begin{array}{l}\text { Number of each colour class in a } \\
\text { moving window of } 3 \times 3 \text { pixels. }\end{array}$ & $\begin{array}{l}\mathrm{CIR} \\
\text { image }\end{array}$ & $\begin{array}{l}24 \\
24 \\
\end{array}$ & $\begin{array}{l}\text { Mean and } \\
\text { variance values }\end{array}$ & $\begin{array}{l}\text { Textural characteristics of the } \\
\text { vegetation segment }\end{array}$ \\
\hline \multicolumn{6}{|l|}{ Topographical vaniables } \\
\hline $\begin{array}{l}\text { Exposure25 (2 layers): } \\
\text { Slope25 } \\
\text { Aspect25 }\end{array}$ & $\begin{array}{l}\text { Direction (aspect) and degree (slope) of } \\
\text { maximum rate of change in } z \text { value from } \\
\text { each cell, expressed in positive degrees } \\
\text { from } 0 \text { to } 90 \text { (slope) and } 0 \text { to } 360 \\
\text { (aspect) }\end{array}$ & $\begin{array}{l}\text { DTM } \\
(25 \mathrm{~m})\end{array}$ & 3 & $\begin{array}{l}\text { Mean slope, } \\
\text { north- and east- } \\
\text { exposed fractions } \\
\text { at the polygon } \\
\text { centroid }\end{array}$ & $\begin{array}{l}\text { Broad-scale surface energy budget, } \\
\text { evapotranspiration and water flow } \\
\text { conditions }\end{array}$ \\
\hline Curvature25 & $\begin{array}{l}\text { Topo-position analysis within a varying } \\
\text { moving window radius of } 10 \text { to } 30 \mathrm{~m} \text { (the } \\
\text { DTM is smoothed and resampled to a } \\
\text { cell size of } 0.5 \mathrm{~m} \text { in advance). For } \\
\text { details see Zimmermann } 2000 \text {. }\end{array}$ & $\begin{array}{l}\text { DTM } \\
(25 \mathrm{~m})\end{array}$ & 3 & $\begin{array}{l}\text { Mean, median } \\
\text { and variance }\end{array}$ & $\begin{array}{l}\text { Broad-scale soil properties and } \\
\text { water flow conditions, topographic } \\
\text { features like ridge, slope, slope } \\
\text { bottom and sink }\end{array}$ \\
\hline Curvature05 & $\begin{array}{l}\text { Topo-position analysis within a varying } \\
\text { moving window radius of } 2 \text { to } 5 \mathrm{~m} \text { in } \\
\text { open land. For details see Zimmermann } \\
2000 \text {. }\end{array}$ & $\begin{array}{l}\text { DSM } \\
(0.5 \mathrm{~m})\end{array}$ & 3 & $\begin{array}{l}\text { Mean, median } \\
\text { and variance }\end{array}$ & $\begin{array}{l}\text { Fine-scale soil properties and soil } \\
\text { water conditions, topographic } \\
\text { features like drainage ditch, } \\
\text { hummock, hollow }\end{array}$ \\
\hline Slope05 & $\begin{array}{l}\text { Degree of maximum rate of change in } z \\
\text { value from each cell, expressed in } \\
\text { positive degrees from } 0 \text { to } 90\end{array}$ & $\begin{array}{l}\text { DSM } \\
(0.5 \mathrm{~m})\end{array}$ & 3 & $\begin{array}{l}\text { Mean, median } \\
\text { and variance }\end{array}$ & $\begin{array}{l}\text { Fine-scale water flow conditions, } \\
\text { surface roughness }\end{array}$ \\
\hline \multicolumn{6}{|l|}{$\begin{array}{l}\text { Topographical-textural } \\
\text { variables }\end{array}$} \\
\hline 8 Slope classes (8 layers) & $\begin{array}{l}\text { Slope classification (8 equidistant } \\
\text { intervals) }\end{array}$ & $\begin{array}{l}\text { DSM } \\
(0.5 \mathrm{~m})\end{array}$ & 8 & $\begin{array}{l}\text { Relative } \\
\text { proportions }\end{array}$ & Surface composition \\
\hline $\begin{array}{l}\text { Slope class agglomeration } \\
\text { (8layers) }\end{array}$ & $\begin{array}{l}\text { Number of each colour class in a } \\
\text { moving window ( } 3 \times 3 \text { pixels). }\end{array}$ & $\begin{array}{l}\text { DSM } \\
(0.5 \mathrm{~m})\end{array}$ & $\begin{array}{l}8 \\
8\end{array}$ & $\begin{array}{l}\text { Mean and } \\
\text { variance values }\end{array}$ & Surface roughness \\
\hline
\end{tabular}


Since model performance decreases when the number of observations (i.e., calibration data) does not markedly exceed the number of predictor variables due to overfitting effects (Draper and Smith 1998, Harrell 2001), the number of predictor variables has to be minimised. The commonly used method to reduce the number of predictor variables is stepwise model selection (Miller 1984, Miller 1990, Draper and Smith 1998). In this study, we apply an equivalent procedure termed composite linear modelling to avoid possible loss of predictive power due to variable dropping. The method was designed to optimally trade interpretation, prediction and sample size needs in the given case of surplus noisy and multi-collinear predictors. It consists of two steps: (1) fitting individual sub-models to thematically coherent groups of predictor variables, (2) fitting a final model to the fitted values resulting from the sub-models. Both modelling steps are applied to the same response variable. Thus, the sub-models produce a reduced number of thematically well-defined predictors which replace the original inputs in the regression (Küchler et al. 2004).

The spatial dependence of the model residuals is used to further improve the results. Ordinary kriging (Cressie 1993) is applied to the residuals of the calibration data to estimate the theoretical residuals of the predicted polygons. The resulting values are added to the predictions of the regression model. The kriging parameters are determined by fitting a spherical variogram, starting with a robust empirical variogram estimation (Cressie and Hawkins 1980, Miller 2005).

Model accuracy is tested by comparing predictions with control observations which are not used for calibration. Thus, model validation relies on reference mire objects where extensive field survey was done. Model performance is quantified by calculating correlation values between predictions and corresponding observed control data. To reflect the absolute degree of error we compute the $95 \%$ quantiles and the error median ( $=50 \%$ quantile). To evaluate the effect of sample size, we quantify model performance for soil reaction using 200 and 70 field records.

Exploring minimum demands on data investments. Cost-efficiency is essential for any long-term monitoring projects and in particular for in-depth habitat monitoring, where costly field data and VHSR imagery are involved. For this purpose we explore the dependence of mapping accuracy on the resolution of the data sources employed.

We let the reliability of modelled error estimates be the main criterion to determine the minimum sample size required for mapping. We fit models using a varying number of training data sets and compare the modelled $95 \%$ prediction intervals to the corresponding observed error quantiles in a test data set. The prediction intervals are calculated at the centre of the predictor variable data range. The minimum sample size is further constrained to ensure model accuracies that comply with the given monitoring tasks.
To evaluate the benefit of the employed CIR aerial images (grid spacing of $30 \mathrm{~cm}$ ), they are compared with images with ground resolutions of $5 \mathrm{~m}$ and $15 \mathrm{~m}$, again in terms of resulting model accuracy. As real satellite images were not available for the reference mire, we use coarsened CIR images to mimic the resolution of satellite images. These images are derived from the high resolution CIR orthophoto by pixel aggregation. Thus, the cells of the reduced-resolution images contain the mean values of the merged cells. The resulting coarse image of $15 \mathrm{~m}$ ground resolution approximately conforms to ASTER satellite data with respect to colour bands and ground resolution.

From the predictor variables mentioned above, we choose only those which can be derived from the spectral data sources. Thus modelling based on simulated satellite images cannot include topographical variables derived from fine-scale surface models. This precise surface information is generated from high resolution aerial photographs by automated stereo matching and is not available with common satellite images.

Model comparison is hindered by missing values, as the satellite-based models fail to predict small surfaces. Predictions are not available for 31 and 408 surfaces, respectively (see Fig. 6). To ensure meaningful model comparison, we use loess regression (Cleveland and Devlin 1988) to locally interpolate the missing values, before the model validation is performed.

\section{Results}

Mean indicator variables are sampled and continuously mapped across the entire mire site. Exemplary model results (Fig. 3) are presented for the reference mire Gross Moos, where field data cover the whole area. In this step, 200 field records are used as calibration data to predict the distribution of eight indicator variables for the whole area under observation (1030 surfaces). The resulting predictive maps depict the varying patterns of essential floristic gradients at the stand level. Model validation (Table 2) proves high model accuracy, showing correlation values above 0.7 for all indicator types except continentality. The $95 \%$ quantiles vary between 0.1 and 0.7 and the medians do not exceed 0.24.

To reflect the effect of the training data size, we model mean soil reaction first with 200 and then with 70 field re-

Table 2. Validation results of eight predicted mean indicator values within the reference mire Gross Moos 1996. 200 field records were used for model calibration. $(\mathrm{r}=$ correlation, med $=$ $50 \%$ quantile, $\mathrm{Q} 95=95 \%$ quantile).

\begin{tabular}{lccc}
\hline & $\mathbf{r}$ & med & Q95 \\
\hline Moisture & 0.73 & 0.12 & 0.35 \\
Light & 0.75 & 0.07 & 0.22 \\
Temperature & 0.79 & 0.04 & 0.17 \\
Continentality & 0.49 & 0.02 & 0.1 \\
Soil reaction & 0.77 & 0.24 & 0.71 \\
Nutrients & 0.82 & 0.19 & 0.65 \\
Humosity & 0.79 & 0.22 & 0.65 \\
Dispersity & 0.75 & 0.08 & 0.29 \\
\hline
\end{tabular}


cords and compare the results. Fig. 4 depicts the mapping results. The key figures indicate that model accuracy of the second model is lower but predictions still yield valuable results $(\mathrm{r}=0.74$, med $=0.26$, Q95 $=0.85)$.

Obviously, model performance depends on the number of survey records used for model calibration. To determine the number of field records necessary to ensure satisfactory

\section{Humosity}

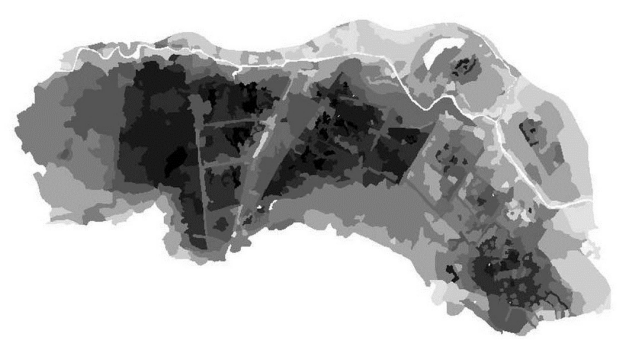

Moisture

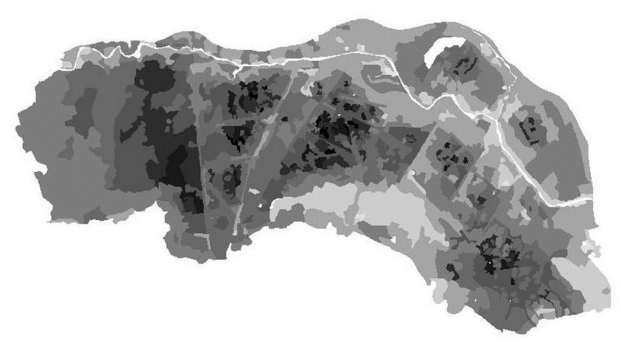

Light

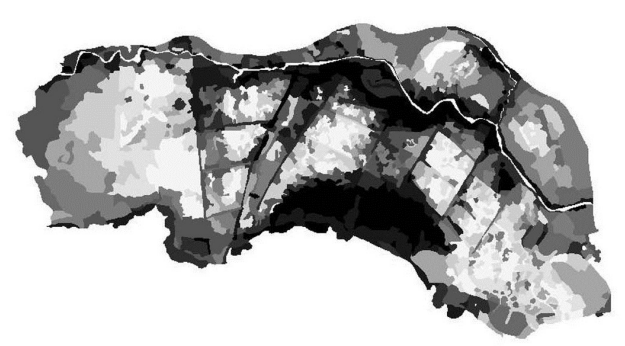

Nutrient

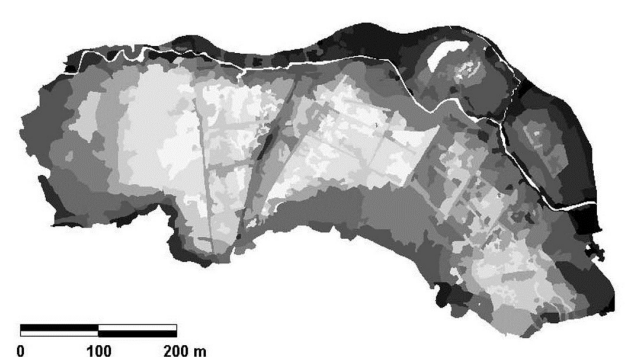

model performance, model validation is repeatedly calculated for a rising number of calibration data. Fig. 5 shows the corresponding decline of the $95 \%$ quantiles with four indicator variables. The performance is depicted for actual errors observed by model validation and those predicted by the model. To gain optimal model predictions for all indicator values, the sample size has to be chosen in a range where the

\section{Soil reaction}

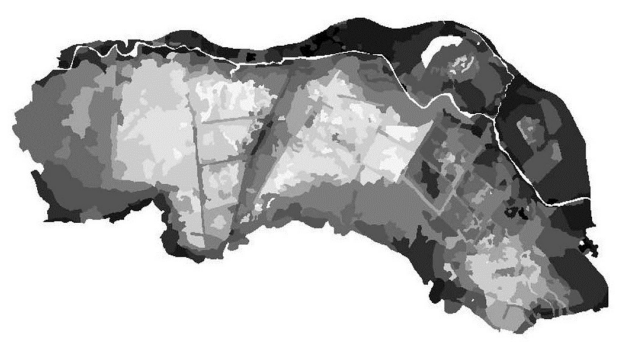

Continentality

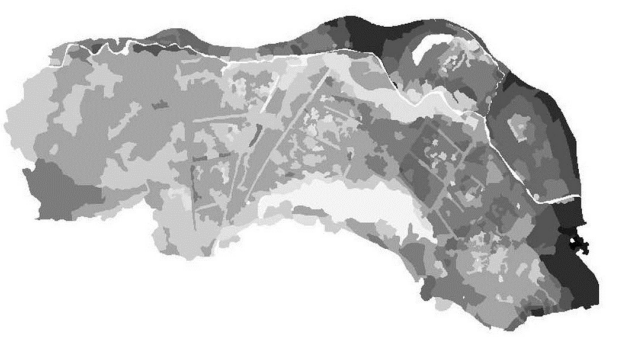

Temperature

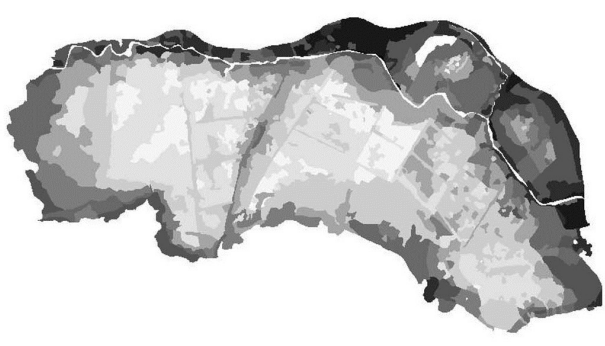

Dispersity

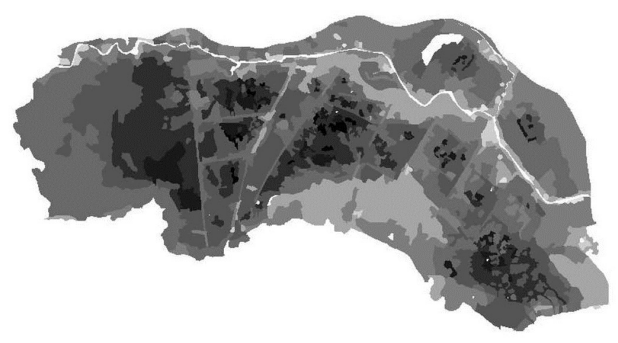

Figure 3. Predictive maps of eight mean indicator variables describing the state of the mire ecosystem in spatial and ecological detail. Dark shading indicates high values of the respective floristic site condition. 


\section{Full field survey:}

\section{Soil reaction:}

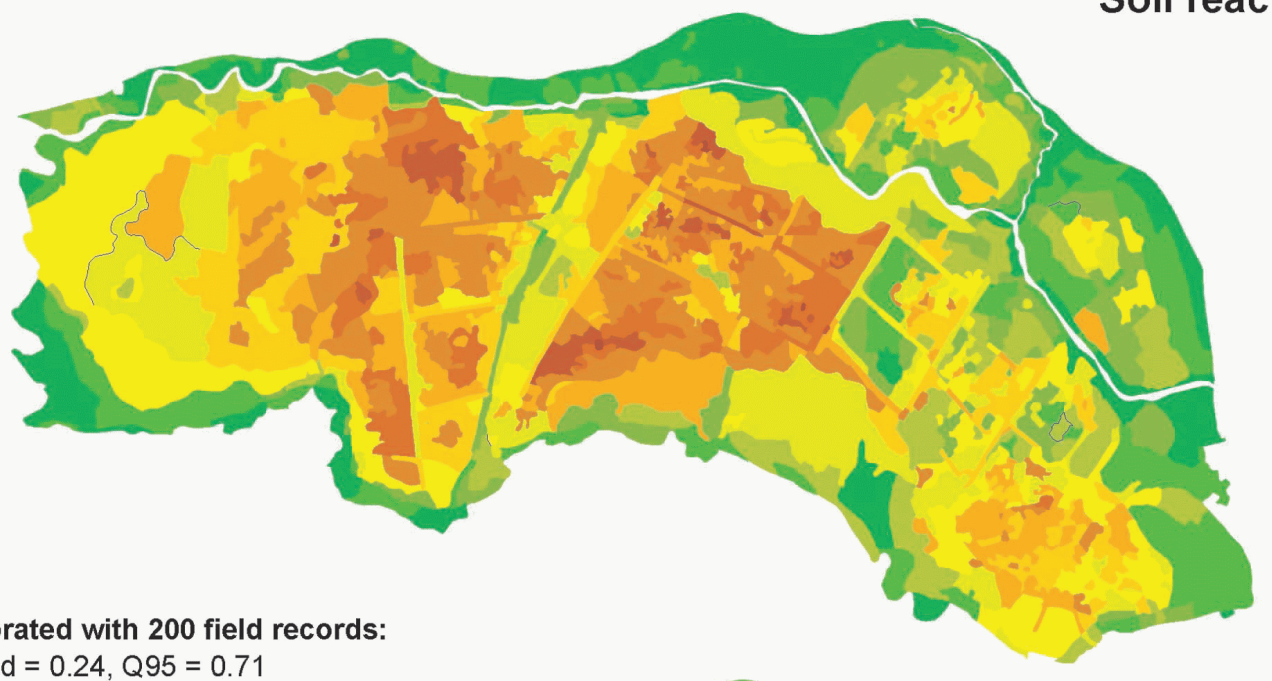

$r=0.77$, med $=0.24, Q 95=0.71$

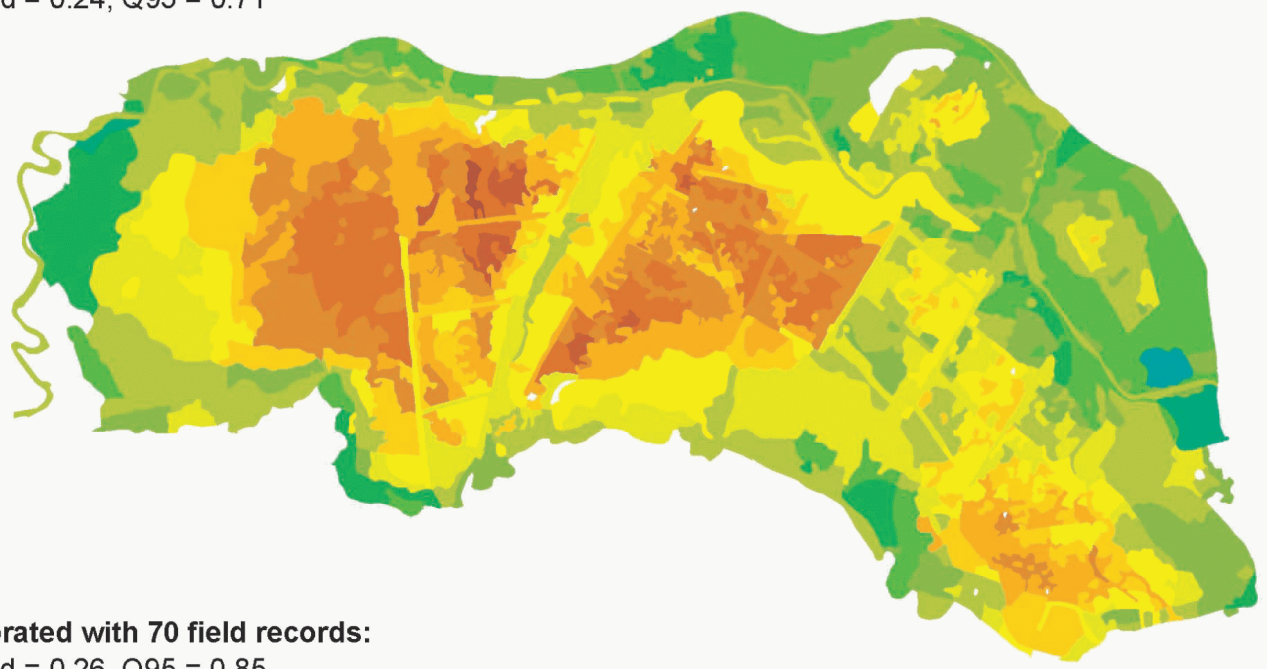

$r=0.74$, med $=0.26, Q 95=0.85$

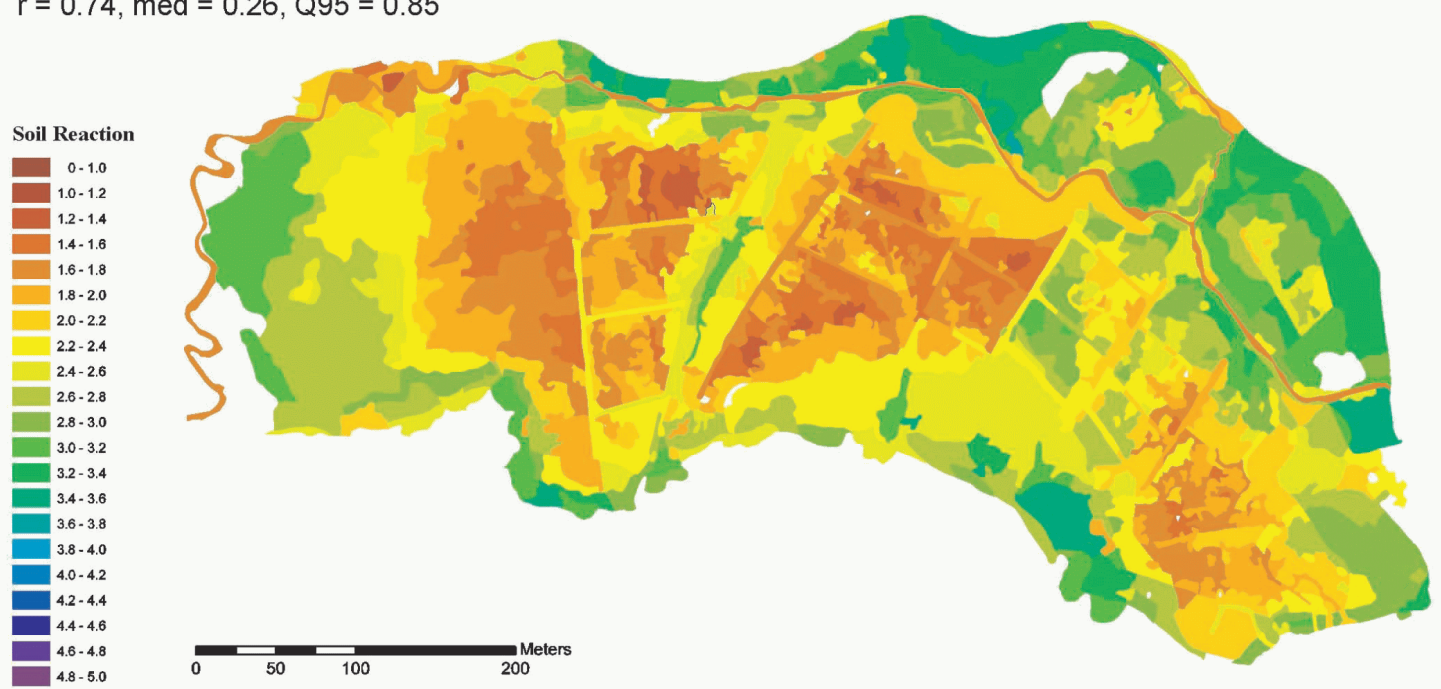

Figure 4. Observed vs. predicted mean soil reaction. Model performance depends on the number of field records used for model calibration. $(r=$ correlation, $\operatorname{med}=50 \%$ quantile, $\mathrm{Q} 95=95 \%$ quantile $)$. 


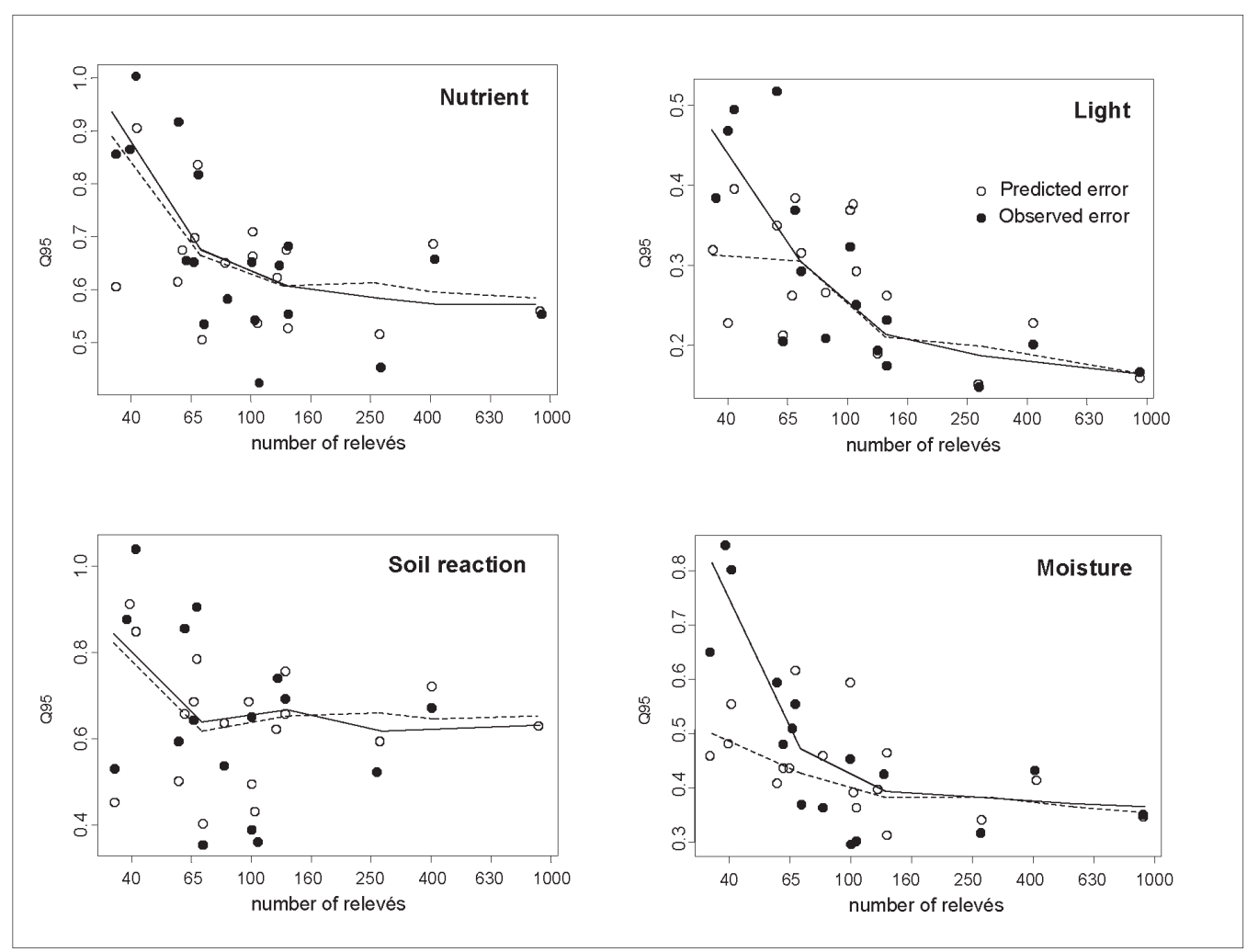

Figure 5. Number of calibration data used for modelling linked to the resulting model accuracy (Q95 $=95 \%$ quantile). The chart shows the corresponding decline of two types of errors: the actual error observed by model validation (full spheres, solid lines) and the one predicted by the model (open spheres, dotted lines). To achieve optimal predictions the error curves should be near their minimum. To additionally obtain reliable error estimates the predicted errors should not differ from the observed ones. Thus at least 100 field records are needed for model calibration within the reference mire.

individual error curves flatten to their minimum. Thus, we see that at least 100 field records are required to guarantee high prediction quality. To additionally assure reliable error estimates, the curves of the predicted errors have to match those of the observed ones. As this is true for the stated sample size, the resulting error estimates are to be considered unbiased. The corresponding $95 \%$ error quantiles of 0.7 and below are supposed to satisfy the given monitoring requirements.

To estimate the benefit from high resolution aerial photographs, corresponding predictions are compared to models based on simulated satellite images. Results show that images of lower resolution produce lower model accuracy (Fig. 6). But predictions based on satellite images of $5 \mathrm{~m}$ ground resolution still produce useful results $(\mathrm{r}=0.59, \mathrm{med}=0.13$, $\mathrm{Q} 95=0.41$ ). Even the coarse image of $15 \mathrm{~m}$ ground resolution detects the main environmental gradients, though extreme values are systematically smoothed $(r=0.43$, med $=$ 0.15 , Q95 = 0.45).

\section{Discussion}

The present study explores the potential of semi-quantitative averaged indicator values and aerial photographs to monitor habitat qualities with regard to investment needs and pre-defined accuracy standards.

\section{Adequate monitoring design}

Various authors criticise that most conservation monitoring programs fail to meet their stated objectives (Yoccoz et al. 2001, Legg and Nagy 2006, Field et al. 2007). To achieve high monitoring quality, the approach presented in this study is based on a two-fold stratified random sampling design and repeated recording of semi-quantitative measures of habitat conditions. The latter implies signed rank tests to be applied to infer hard statistics about changes at a strategic sub-national level. To provide this information to land managers at the local scale in spatial detail, predictive mapping of respective gradients at the stand level is applied in all 124 sample habitats and some additional reference mires, where conservation or restoration measures have been taken. Küchler et al. (2007) use resulting model estimates for valid change detection.

\section{Limitations of stand-alone remote sensing applications}

Plant communities constitute the primary component of terrestrial ecosystem structure and functioning. Hence, they 
Aerial photograph $(0.3 \mathrm{~m})$ :

Moisture:

$r=0.73$, med $=0.12, \mathrm{Q} 95=0.35, \mathrm{NA}=0$

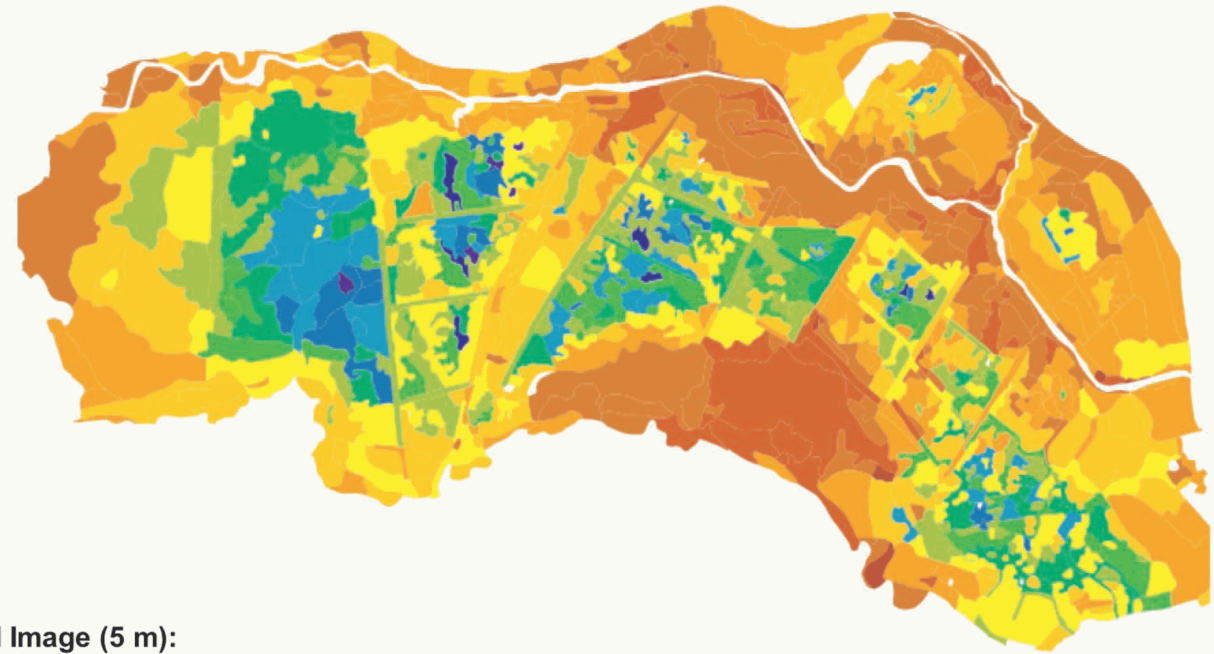

Simulated Image $(5 \mathrm{~m})$ :

$r=0.59$, med $=0.13, Q 95=0.41, N A: 31$

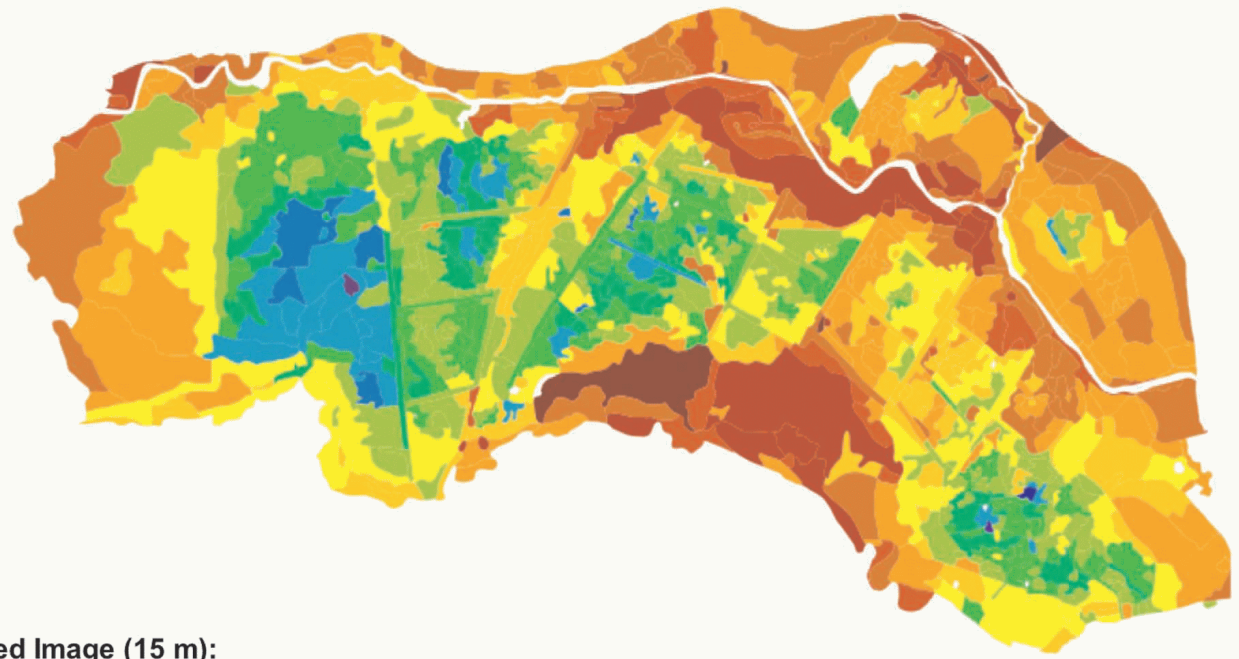

Simulated Image (15 $\mathrm{m})$ :

$r=0.43$, med $=0.15$, Q95 $=0.45, N A: 408$

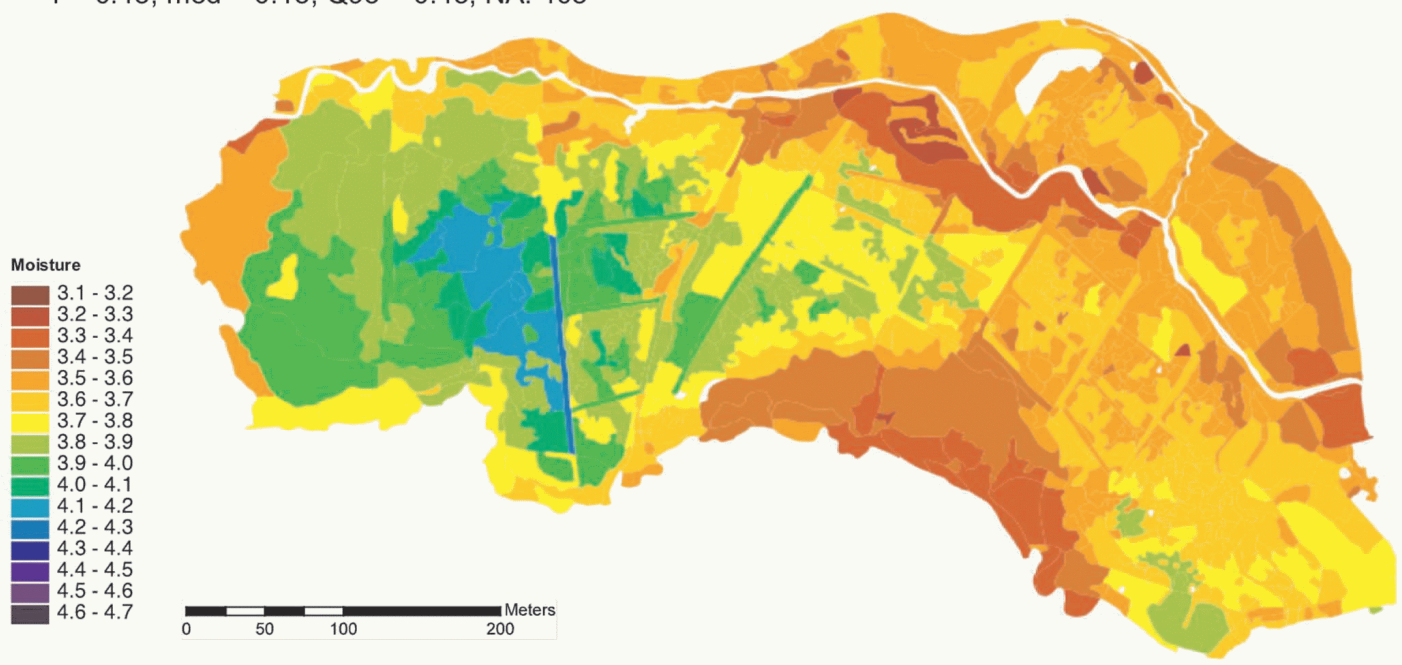

Figu re 6. Modelled distribution of moisture based on CIR aerial orthophotos vs. simulated satellite data of 5 and $15 \mathrm{~m}$ ground resolution. Missing values (NA) of the satellite-based models are interpolated by loess regression to enable consistent model comparison. $(\mathrm{r}=$ correlation, $\mathrm{Q} 95=95 \%$ quantile, med $=50 \%$ quantile $)$. 
are considered essential in determining ecosystem quality and condition (e.g., conservation status) (Bunce et al. 2008). Remote sensing can provide corresponding broad spatial and multi-temporal information. Although there have been considerable advances in sensor technology, vegetation mapping and wetland monitoring have remained a difficult task. Most studies using remotely sensed data discriminate at the level of major physiognomic categories. However, on the herbaceous and grass level, there have been few successful mapping results, e.g., for salt-marsh vegetation (Schmidt et al. 2004, Toyra and Pietroniro 2005, Belluco et al. 2006). As a consequence, there is still no operational application to monitor complex ecosystems such as European priority habitats (Bunce et al. 2008). Due to the lack of field data, recent case studies assessing single habitats in the context of Natura 2000 were thematically limited to crude vegetation types or structural indicators of vague ecological meaning (Weiers et al. 2004, Bock et al. 2005, Keramitsoglou et al. 2006, Langanke et al. 2007).

\section{Choice of ancillary field information}

The approach of linking floristic field information to aerial photographs is demonstrated by the Swiss mire monitoring program. Instead of using qualitative categories of plant communities, Landolt plant indicator values (Landolt 1977) are employed as a derived measure of habitat quality. While there is a substantial body of literature discussing the limitations of indicator values (for an overview see Diekmann 2003 and Schmidtlein 2005) and the way how to use them in statistical analysis (ter Braak and Looman 1986, Jongman et al. 1995), semi-quantitative mean indicator values are still considered as a sound measure to describe floristic conditions on the stand level (Graf 1996, Diekmann and Dupre 1997, Hawkes et al. 1997, Ertsen et al. 1998, Diekmann 2003, Gegout et al. 2003, Rosenthal 2003, Large et al. 2007). However, mean indicator values do not reflect momentary habitat conditions, but lifespan growth conditions of individual species (Schmidtlein 2003). Hence, a time lag has to be considered for the detection of subtle changes. As Ellenberg indicator values were developed for Central Europe, local experience on the ecological amplitude of plant species may be needed for extending the monitoring approach to other parts of Europe.

\section{Sample and indicator robustness}

To obtain reliable monitoring results, common sources of error immanent in conservation monitoring have to be considered (Yoccoz et al. 2001). Inference error usually occurs with weak sample representativeness. The present study takes this type of error into account by establishing a twofold stratified random sampling scheme based on proper model structures at the regional and at the local level. In general, ground truthing is faced with effects such as researcher impact, especially on wetlands (Wolski et al. 2004), observer bias (Kercher et al. 2003), relocation problems, border effects or simple overlooking and species misidentification
(Scott and Hallam 2003). Another source of inaccuracy is the varying detectability or seasonality of biotic monitoring objects (MacKenzie and Kendall 2002, Royle and Nichols 2003, Schmidt 2003, Kery and Schmid 2004). All these aspects inevitably affect the quality of the field data. We argue, that most of these errors are minimised by monitoring robust mean indicator values. As these values reflect the realized optima of a species assemblage within a stand, single species or fine-scale spatial irregularities do not affect the resulting observation significantly. Additionally, operating on quasimetric indicator variables avoids statistical limitations of count data analysis and simplification errors intrinsic to classifications, such as vegetation classes.

\section{Mapping techniques}

Mean indicator values show various links to reflectance properties of vegetation and topographical characteristics (Schmidtlein 2005). Thus the combination of both data sources is likely to predict floristic gradients over the whole area of observation. Continuous mapping can be easily achieved by regression analysis. In traditional remote sensing, most regression models rely on a single spectral vegetation index (Cohen et al. 2003). As regression suffers from multicollinearity with modern multispectral data, other methods have to be employed for such data. Partial least squares regression, for example, has been successfully used with hyperspectral imagery (Schmidtlein 2005, Cho et al. 2007). In this study, we employ composite linear modelling to circumvent the problem of variable-reduction (Küchler et al. 2004). A general drawback of such empirical models is that they cannot be projected to sites other than where they were developed.

\section{Appropriate VHR remote sensing images}

Various authors investigated the impact of remotely sensed data sources of diverse spectral and spatial resolution on the mapping of priority habitats in nature conservation (Toyra and Pietroniro 2005). Hyperspectral data contain largely redundant information. Accordingly, spatial resolution might affect mapping accuracy more than spectral resolution, as reduction experiments showed for mapping saltmarsh vegetation (Belluco et al. 2006). In this study, we demonstrate the benefit of aerial orthophotos for mapping floristic gradients at the stand level. In fact, aerial photography continues to be an important source for small area monitoring of wetland conservation and restoration (Shuman and Ambrose 2003, Langanke et al. 2007, Waser et al. 2008). This is due to its unrivalled spatial resolution and its capacity to assess the vertical dimension of vegetation by the means of stereo matching techniques (Fensham and Fairfax 2002).

On the other hand, acquisition or processing of digital orthophotos is time-consuming and costly. Problems also arise from the radiometric correction of aerial photographs taken from different flight series. Thus, we are faced with a declining quality of spectral information with composed orthophotos covering broader areas. As satellite remote sensing pro- 
vides larger spatial views, they do not suffer from those limitations. In this paper, coarsened images of respective ground resolutions still prove high potential to map floristic gradients at the stand level resolution. Hence, satellite images might be a promising data source to assess floristic habitat qualities at the stand level and over larger areas.

\section{Sample size requirements}

Other authors examined the dependence of mapping quality on the thematic resolution and amount of training data used to calibrate the model (Bates et al. 2007, Marignani et al. 2007). In this study, the chosen thematic resolution is considered to be indispensable to meet the given monitoring tasks. Thus, we explore the impact of sample size. With the reference mire tested, at least 100 field records are required to guarantee optimal prediction accuracy and reliable error estimates. The resulting $95 \%$ error quantiles are below 0.7 for all indicator variables tested. The number of 100 relevés constitutes a sample reduction of $90 \%$ compared to field based methods surveying the entire reference mire. However, the required sample size depends on the size and heterogeneity of a site. As a general rule of thumb, cost-effectiveness of field work increases with broad or less complex sites. Hence, the optimal sample effort has to be determined for all 124 sample mires individually.

\section{Conclusion}

The Swiss mire monitoring approach presented in this study is designed to provide consistent figures on habitat loss and habitat state for a small-sized priority habitat of nature conservation. To capture habitat qualities in sufficient detail, limited vegetation recording is indispensable, but costs are supposed to be outweighed by the in-depth ecological information it provides to calibrate VHR remote sensing data that are per se ecologically meaningless. Monitoring results are robust, readily applicable for management purposes and understandable to policy makers and land managers not familiar with vegetation categories or plants. Thus, they have implications on the strategic level of regional conservation policy as well as on the implementation of local conservation measures. Since such monitoring might be applicable across a range of habitat types, we argue that it has the potential to become a standard method for operational monitoring of priority habitats in nature conservation.

Acknowledgements: We are grateful to G. Pfundner for her assistance in the field work. We thank P. Longatti and R. Ghosh for the English revision. The monitoring program was funded by the Swiss Federal Office for the Environment FOEN.

\section{References}

Bates, C. R., G. Scott, M. Tobin and R. Thompson. 2007. Weighing the costs and benefits of reduced sampling resolution in biomonitoring studies: Perspectives from the temperate rocky intertidal. Biol. Conserv. 137:617-625.
Belluco, E., M. Camuffo, S. Ferrari, L. Modenese, S. Silvestri, A Marani and M. Marani. 2006. Mapping salt-marsh vegetation by multispectral and hyperspectral remote sensing. Remote Sensing of Environment 105:54-67.

Bock, M., G. Rossner, M. Wissen, K. Remm, T. Langanke, S. Lang, H. Klug, T. Blaschke and B. Vrscaj. 2005. Spatial indicators for nature conservation from European to local scale. Ecol. Indicators 5:322-338.

Broggi, M. F. 1990. Inventar der Flachmoore von nationaler Bedeutung. Entwurffür die Vernehmlassung. / Inventaire des bas-marais d'importance nationale. Projet mis en consultation. I Inventario delle paludi d'importanza nazionale. Progetto presentato in consultazione. Eidgenöss. Depart. des Innern (EDI) / Dép. féd. de l'intérieur (DFI) / Dip. fed. dell'Interno (DFI) ed. Bern, BUWAL (Bundesamt für Umwelt, Wald und Landschaft)/ Berne, OFEFFP (Office fédéral de l'environnement, des forêts et du paysage) / Berna, UFAFP (Ufficio federale dell' ambiante, delle foreste e del paesaggio).

Bunce, R. G. H., M. J. Metzger, R. H. G. Jongman, J. Brandt, G. De Blust, R. Elena-Rossello, G. B. Groom, L. Halada, G. Hofer, D. C. Howard, P. Kovar, C. A. Mucher, E. Padoa-Schioppa, D. Paelinx, A. Palo, M. Perez-Soba, I. L. Ramos, P. Roche, H. Skanes and T. Wrbka. 2008. A standardized procedure for surveillance and monitoring European habitats and provision of spatial data. Landsc. Ecol. 23:11-25.

Cho, M. A., A. Skidmore, F. Corsi, S. E. van Wieren and I. Sobhan. 2007. Estimation of green grass/herb biomass from airborne hyperspectral imagery using spectral indices and partial least squares regression. International J. Applied Earth Observation Geoinformation 9:414-424.

Christensen, N., A. Bartuska, J. Brown and e. al. 1996. The report of the ecological society of America committee on the scientific basis for ecosystem management. Ecol. App. 6:665-691.

Cleveland, W. S. and S. J. Devlin. 1988. Locally-weighted regression: An approach to regression analysis by local fitting. J. Am. Statist. Assoc. 83:596-610.

Cohen, W. B., T. K. Maiersperger, S. T. Gower and D. P. Turner. 2003. An improved strategy for regression of biophysical variables and Landsat ETM+ data. Remote Sensing of Environment 84:561-571.

Cressie, N. 1993. Statistics for Spatial Data. Revised edition. Wiley, New York.

Cressie, N. and D.H. Hawkins. 1980. Robust estimation of the variogram I. Math. Geol. 12:115-125.

Diekmann, M. 2003. Species indicator values as an important tool in applied plant ecology - a review. Basic App. Ecol. 4:493-506.

Diekmann, M. and C. Dupre. 1997. Acidification and eutrophication of deciduous forests in northwestern Germany demonstrated by indicator species analysis. J. Veg. Sci. 8:855-864.

Dirnböck, T., R. J. Hobbs, R. J. Lambeck and P. A. Caccetta. 2002. Vegetation distribution in relation to topographically driven processes in southwestern Australia. App. Veg. Sci. 5:147-158.

Draper, N. R. and H. Smith. 1998. Applied Regression Analysis. Wiley, New York.

Ellenberg, H. 1974. Zeigerwerte der Gefässpflanzen Mitteleuropas. Scripta Geobot. 9:97.

Ellenberg, H., H. E. Webwe, R. Düll, V. Wirth, W. Werner and D. Paulissen. 1992. Zeigerwerte von Pflanzen in Mitteleuropa. Scripta Geobot. 18:1-248.

Ertsen, A. C. D., J. R. M. Alkemade and M. J. Wassen. 1998. Calibrating Ellenberg indicator values for moisture, acidity, nutrient 
availability and salinity in the Netherlands. Plant Ecol. 135:113124.

Fassnacht, K. S., W. B. Cohen and T. A. Spies. 2006. Key issues in making and using satellite-based maps in ecology: A primer. Forest Ecol. Manage. 222:167-181.

Feldmeyer-Christe, E., K. Ecker, M. Küchler, U. Graf and L. T. Waser. 2007. Improving predictive mapping in Swiss mire ecosystems through re-calibration of indicator values. App. Veg. Sci. 10:183-192.

Feldmeyer-Christe, E. and H. Küchler. 2002. Onze ans de dynamique de la vegetation dans une tourbiere soumise a un glissement de terrain. Bot. Helv. 112:103-120.

Fensham, R. J. and R. J. Fairfax. 2002. Aerial photography for assessing vegetation change: a review of applications and the relevance of findings for Australian vegetation history. Aust. J. Bot. 50:415-429.

Ferreira, J. G., C. Vale, C. V. Soares, F. Salas, P. E. Stacey, S. B. Bricker, M. C. Silva and J. C. Marques. 2007. Monitoring of coastal and transitional waters under the EU water framework directive. Environmental Monitoring and Assessment 135:195216.

Field, S. A., P. J. O'Connor, A. J. Tyre and H. P. Possingham. 2007. Making monitoring meaningful. Aust. Ecol. 32:485-491.

Gegout, J. C., J. C. Herve, F. Houllier and J. C. Pierrat. 2003. Prediction of forest soil nutrient status using vegetation. J. Veg. Sci. 14:55-62.

Graf, U. 1996. Indication of soil nutrients in litter meadows. Veröffentlichungen des geobotanischen Institutes der ETH, Stiftung Rübel, Zürich.

Grandin, U. 2004. Dynamics of understory vegetation in boreal forests: experiences from Swedish integrated monitoring sites. Forest Ecol. Manage. 195:45-55.

Grünig, A., L. Vetterli and O. Wildi. 1986. Die Hoch- und Uebergangsmoore der Schweiz - eine Inventarauswertung. / Les hauts-marais et marais de transition de Suisse - résultats d'un inventaire. Eidgenössische Forschungsanstalt für Wald, Schnee und Landschaft, Bericht 281, Birmensdorf.

Harrell, F. E. 2001. Regression Modeling Strategies: with Applications to Linear Models, Logistic Regression and Survival Analysis. Springer, New York.

Hawkes, J. C., D. G. Pyatt and I. M. S. White. 1997. Using Ellenberg indicator values to assess soil quality in British forests from ground vegetation: A pilot study. J. App. Ecol. 34:375-387.

Hellawell, J. M. 1991. Development of a rationale for monitoring. In: B. Goldsmith (ed.), Monitoring for Conservation and Ecology. Chapman and Hall, London. pp. 1-14.

Hutchinson, G. E. 1957. Concluding remarks. Cold Spring Harbor Symp. Quant. Biol. 22:415-427.

Jongman, R. H., O. F. R. Van Tongeren and C. J. F. ter Braak. 1995. Data Analysis in Community and Landscape Ecology. Cambridge Univ. Press, Cambridge.

Keramitsoglou, I., H. Sarimveis, C. T. Kiranoudis, C. Kontoes, N. Sifakis and E. Fitoka. 2006. The performance of pixel window algorithms in the classification of habitats using VHSR imagery. Isprs Journal of Photogrammetry and Remote Sensing 60:225238.

Kercher, S. M., C. B. Frieswyk and J. B. Zedler. 2003. Effects of sampling teams and estimation methods on the assessment of plant cover. J. Veg. Sci. 14:899-906.

Kerr, J. T. and I. Deguise. 2004. Habitat loss and the limits to endangered species recovery. Ecol. Lett. 7:1163-1169.
Kerr, J. T. and M. Ostrovsky. 2003. From space to species: ecological applications for remote sensing. Trends in Ecology \& Evolution 18:299-305.

Kery, M. and H. Schmid. 2004. Monitoring programs need to take into account imperfect species detectability. Basic App. Ecol. 5:65-73.

Kleijn, D., R. A. Baquero, Y. Clough, M. Diaz, J. De Esteban, F. Fernandez, D. Gabriel, F. Herzog, A. Holzschuh, R. Johl, E. Knop, A. Kruess, E. J. P. Marshall, I. Steffan-Dewenter, T. Tscharntke, J. Verhulst, T. M. West and J. L. Yela. 2006. Mixed biodiversity benefits of agri-environment schemes in five European countries. Ecol. Lett. 9:243-254.

Küchler, M., K. Ecker, E. Feldmeyer-Christe, U. Graf, H. Küchler and L. T. Waser. 2004. Combining remotely sensed spectral data and digital surface models for fine-scale modelling of mire ecosystems. Community Ecol. 5:55-68.

Küchler, M., K. Ecker, E. Feldmeyer, U. Graf and L. T. Waser. 2007. Predictive models of mire habitats: bias in detection of changes. In: J. Kubrak, T. Okruszko and S. Ignar (eds.), Wetlands: Monitoring, Modelling and Management. Taylor \& Francis Group, London. pp. 91-100.

Landolt, E. 1977. Ökologische Zeigerwerte zur Schweizer Flora. Veröffentlichungen des Geobotanischen Institutes der Eidg. Techn. Hochschule, Stiftung Rübel, Zürich.

Langanke, T., C. Burnett and S. Lang. 2007. Assessing the mire conservation status of a raised bog site in Salzburg using objectbased monitoring and structural analysis. Landscape and Urban Planning 79:160-169.

Large, A. R. G., W. M. Mayes, M. D. Newson and G. Parkin. 2007. Using long-term monitoring of fen hydrology and vegetation to underpin wetland restoration strategies. App. Veg. Sci. 10:417428.

Legg, C. J. and L. Nagy. 2006. Why most conservation monitoring is, but need not be, a waste of time. J. Environ. Manage. 78:194199.

MacKenzie, D. I. and W. L. Kendall. 2002. How should detection probability be incorporated into estimates of relative abundance? Ecology 83:2387-2393.

Marignani, M., E. Del Vico and S. Maccherini. 2007. Spatial scale and sampling size affect the concordance between remotely sensed information and plant community discrimination in restoration monitoring. Biodiversity and Conserv. 16:3851-3861.

McRoberts, R. E. 2006. A model-based approach to estimating forest area. Remote Sensing of Environment 103:56-66.

Miller, A. J. 1984. Selection of subsets of regression variables. Journal of the Royal Statistical Society Series a-Statistics in Society 147:389-425.

Miller, A. J. 1990. Subset Selection in Regression. Chapman \& Hall, London.

Miller, J. 2005. Incorporating spatial dependence in predictive vegetation models: Residual interpolation methods. Professional Geographer 57:169-184.

Moore, I. D., R. B. Grayson and A. R. Ladson. 1991. Digital terrain modeling - a review of hydrological, geomorphological, and biological applications. Hydrological Processes 5:3-30.

Nichols, J. D. and B. K. Williams. 2006. Monitoring for conservation. Trends in Ecology \& Evolution 21:668-673.

Pereira, H. M. and H. D. Cooper. 2006. Towards the global monitoring of biodiversity change. Trends in Ecology \& Evolution 21:123-129. 
Pietroniro, A. and R. Leconte. 2005. A review of Canadian remote sensing and hydrology, 1999-2003. Hydrological Processes 19:285-301.

Rosenthal, G. 2003. Selecting target species to evaluate the success of wet grassland restoration. Agriculture Ecosystems \& Environment 98:227-246.

Royle, J. A. and J. D. Nichols. 2003. Estimating abundance from repeated presence-absence data or point counts. Ecology 84:777-790.

Schlittgen, R. 2000. Einführung in die Statistik: Analyse und Modellierung von Daten. R. Oldenbourg Verlag, München, Wien.

Schmidt, B. R. 2003. Count data, detection probabilities, and the demography, dynamics, distribution, and decline of amphibians. Comptes Rendus Biologies 326:S119-S124.

Schmidt, K. S., A. K. Skidmore, E. H. Kloosterman, H. Van Oosten, L. Kumar and J. A. M. Janssen. 2004. Mapping coastal vegetation using an expert system and hyperspectral imagery. Photogrammetric Engineering and Remote Sensing 70:703-715.

Schmidtlein, S. 2003. Raster-based detection of vegetation patterns at landscape scale levels. Phytocoenologia 33:603-621.

Schmidtlein, S. 2005. Imaging spectroscopy as a tool for mapping Ellenberg indicator values. J. App. Ecol. 42:966-974.

Schmidtlein, S., P. Zimmermann, R. Schupferling and C. Weiss. 2007. Mapping the floristic continuum: Ordination space position estimated from imaging spectroscopy. J. Veg. Sci. 18:131140 .

Scott, W. A. and C. J. Hallam. 2003. Assessing species misidentification rates through quality assurance of vegetation monitoring. Plant Ecol. 165:101-115.

Seidling, W. 2005. Ground floor vegetation assessment within the intensive (Level II) monitoring of forest ecosystems in Germany: chances and challenges. Eur. J. Forest Res. 124:301-312.

Shuman, C. S. and R. F. Ambrose. 2003. A comparison of remote sensing and ground-based methods for monitoring wetland restoration success. Restoration Ecol. 11:325-333.

Smart, S. M., R. T. Clarke, H. M. van de Poll, E. J. Robertson, E. R. Shield, R. G. H. Bunce and L. C. Maskell. 2003. National-scale vegetation change across Britain; an analysis of sample-based surveillance data from the Countryside Surveys of 1990 and 1998. J. Environmental Manage. 67:239-254.

ter Braak, C. J. F. and C. W. N. Looman. 1986. Weighted averaging, logistic-regression and the gaussian response model. Vegetatio 65:3-11.
Toyra, J. and A. Pietroniro. 2005. Towards operational monitoring of a northern wetland using geomatics-based techniques. Remote Sensing of Environment 97:174-191.

Turner, W., S. Spector, N. Gardiner, M. Fladeland, E. Sterling and M. Steininger. 2003. Remote sensing for biodiversity science and conservation. Trends in Ecology \& Evolution 18:306-314.

Vos, P., E. Meelis and W. J. Ter Keurs. 2000. A framework for the design of ecological monitoring programs as a tool for environmental and nature management. Environmental Monitoring and Assessment 61:317-344.

Waser, L. T., E. Baltsavias, K. Ecker, H. Eisenbeiss, E. FeldmeyerChriste, C. Ginzler, M. Küchler and L. Zhang. 2008. Assessing changes of forest area and shrub encroachment in a mire ecosystem using digital surface models and CIR-aerial images. Remote Sensing of Environment 112:1956-1968.

Weiers, S., M. Bock, M. Wissen and G. Rossner. 2004. Mapping and indicator approaches for the assessment of habitats at different scales using remote sensing and GIS methods. Landscape and Urban Planning 67:43-65.

Wolski, L. F., J. C. Trexler, E. B. Nelson, T. Philippi and S. A. Perry. 2004. Assessing researcher impacts from a long-term sampling program of wetland communities in the Everglades National Park, Florida, USA. Freshwater Biol. 49:1381-1390.

Woodward, A., K. J. Jenkins and E. G. Schreiner. 1999. The role of ecological theory in long-term ecological monitoring: Report on a workshop. Natural Areas J. 19:223-233.

Yoccoz, N. G., J. D. Nichols and T. Boulinier. 2001. Monitoring of biological diversity in space and time. Trends in Ecology \& Evolution 16:446-453.

Zar, J. H. 1986. Biostatistical Analysis. Second edition. Prentice Hall, Upper Saddle River, New Jersey.

Zimmermann, N. E. and F. Kienast. 1999. Predictive mapping of alpine grasslands in Switzerland: Species versus community approach. J. Veg. Sci. 10:469-482.

Zimmermann, N.E. 2000. toposcale.aml: An ArcInfo-script for computation of multi-scale topographic position. http: www.wsl.ch/staff/niklaus.zimmermann/programs/aml4_1.html (Accessed: 12/22/2003).

Received February 26, 2008 Revised August 5, 2008 Accepted October 18,2008 